\title{
NONOSMOTIC EFFECT OF POLYETHYLENE GLYCOL ON PERCENT SURVIVAL AND GROWTH OF RICE
}

\author{
Abouzied, S.T. and Amal L. Abd El-latif \\ Soil Sciences Dept., Fac. of Agriculture, Cairo University, Giza, Egypt
}

Keywords: Nonosmotic, Salinity, Rice, Sodium, Chloride

\section{ABSTRACT}

Salinity is one of the major environmental factors limiting crop productivity. For this reason, two greenhouse experiments were conducted in Faculty of Agriculture, Cairo University, Egypt, during the year 2015 using two rice varieties to evaluate the effects of various levels of osmotic stress caused by polyethylene-glycol 6000 (PEG) and NaCl. Furthermore, it was tested whether the inhibitory effect of salinity on growth, sodium and chloride concentration by two different varieties was greater under $\mathrm{NaCl}$ or PEG treatment. The first experiment was undertaken to separate osmotic and ionic aspects of salinity damage to rice (Oryza sativa L.).Seedlings of IR28 (salt-sensitive) and Nona Bokra (salt-tolerant) rice varieties were transferred to salinized nutrient solution containing $85 \mathrm{~mol} \mathrm{~m}$ ${ }^{3} \mathrm{NaCl}(-3.0$ bars) with or without PEG $6000(-2.0$ bars, $\left.45 \mathrm{gL}^{-1}\right)$. Plants were grown up to 30 days in the salinized solutions. The second experiment was designed to determine the effect of salinity ( 85 $\mathrm{mol} \mathrm{m} \mathrm{m}^{-3} \mathrm{NaCl}$ ) with or without PEG 6000 (-0.5 bar, $11 \mathrm{~g} \mathrm{~L}^{-1}$ )on growth, uptake and transport of sodium and chloride in two rice varieties differing in salt tolerance. The results indicated that survival of salt-tolerant variety (Nona Bokra) was increased significantly by adding PEG (-2.0 bars). The addition of PEG also reduced the rate of death of rice plants compared with $\mathrm{NaCl}$ alone. Also, data showed that PEG 6000 (0.5 bar, $11 \mathrm{gL}^{-1}$ ) reduce sodium concentration in root of IR28 and Nona Bokra but its effect upon sodium concentration in shoot of the two varieties was more pronounced than the reduction of $\mathrm{Na}^{+}$concentration in root. Highly significant differences were obtained between zero and $11 \mathrm{gL}^{-1} \mathrm{PEG}$. The result of this study is strongly indicated that addition of PEG dramatically lessened the toxicity of $\mathrm{NaCl}$ to rice seedlings.

\section{INTRODUCTION}

Rice is one of the most important cereal crop in the world. Three billion people consider rice as their stable food, yielding one - third of the total carbohydrate source. It considers as a salt - sensitive monocot (Darwish et al 2009). One of the main factors that reduce plant growth in many regions in the world is soil salinity. Excessive concentrations of soluble salts, which adversely affect plant growth in the soils that existed in the arid and semiarid regions. There are many salt excessive, in salt-affected soil, especially $\mathrm{NaCl}$. Also, available water in the salty soil is restricted, resulting osmotic stress (Pagter et al 2009 and Siringam et al 2011).

Plant growth differs in its response to salinity. Most plants severely inhibited growth at low salinity levels (Moisender et al 2002). Excessive salt affects plant physiology through ionic and osmotic stress (Murphy and Durako, 2003). Soil water potential and availability of water decreases by the high concentration of salts in the root zone. This causes dehydration at cellular level and ultimately osmotic stress occurs as a result of the deficiency in available water under saline condition. An ionic imbalance may occurred by reducing the uptake of beneficial ions such as $\mathrm{K}^{+}, \mathrm{Ca}^{2+}$ and $\mathrm{Mg}^{2+}$ due to the excessive of toxic ions such as $\mathrm{Na}^{+}$and $\mathrm{Cl}^{-}$ (Hasegawa et al 2000). High $\mathrm{Na}^{+}$concentration adversely affected many enzymatic activities of plants (Maathuis and Amtmann, 1999).

Tolerate salinity is attributed to many mechanisms. These mechanisms include minimizing $\mathrm{Na}^{+}$ uptake by roots and/or increasing $\mathrm{Na}^{+}$efflux back to the soil; potassium retention in the cytosol; tis- 
sue - specific $\mathrm{Na}^{+}$sequestration; osmotic adjustment; intercellular $\mathrm{Na}^{+}$sequestration; control of xylem ion loading; oxidative stress tolerance and excluding $\mathrm{Na}^{+}$from the shoot (Shabala and Munns, 2012). These mechanisms are grouped into three main factors: (1) tissue tolerance mechanisms, (2) osmo-tolerance and (3) sodium exclusion mechanism (Munns and Tester, 2008).

This study was undertaken to examine the nonosmotic effect of PEG on survival and sodium and chloride transport under two different varieties of rice. Also to determine whether the inhibitory effect of salinity on $\mathrm{Cl}$ and $\mathrm{Na}$ content by rice plant was greater under $\mathrm{NaCl}$ or PEG treatment.

\section{MATERIALS AND METHODS}

Experiment 1: Nonosmotic effect of polyethylene Glycols on percent survival

In this experiment, polyethylene Glycols (PEG) was initially employed in its conventional role as an inert osmoticum, to separate osmotic and ionic aspects of salinity damage to rice seedlings. Seeds of IR28 (salt- sensitive) and Nona Bokra (salt - tolerant) varieties were obtained from the International Rice Research Institute, Manila, Philippines. Seeds were surface - sterilized with $0.1 \%$ $\mathrm{HgCl}_{2}$ for 5 minutes and washed twice with distilled water and then soaked for $24 \mathrm{~h}$ in distilled water. The seeds were germinated in petri dishes over three layers of cotton saturated with distilled water. The dishes were then covered and left in the incubator for $48 \mathrm{hr}$ at temperatures between $25-30^{\circ} \mathrm{C}$. The germinated seeds were raised on a nylon net seedbed floating in 7 liter plastic tray containing nutrient solution (Table 1). The experiment was conducted in the greenhouse, natural light intensity and relative humidity was approximately $60 \%$. After 7 days. The seedlings which had grown to threeleaf stage were selected and transplanted into a transferable styrofoam board with 60 holes spaced $2 \mathrm{~cm}$ apart. One seedling was transplanted into each hole and held in place by a foam. Thirty seedlings per variety were included in one replication; The treatments were replicated three times.

The amount of PEG needed to bring the osmotic potential of the nutrient solution to a desired level was estimated from data of Lawlor (1970). The actual osmotic potential was checked with Merrill thermocouple psychrometers (No.75-1). Small strips of filter paper were saturated with PEG solution and inserted into psychrometer cups. The readings were obtained after $1.5 \mathrm{hr}$ of thermal and water vapor equilibrium using a Wescor dew point microvoltmeter (HR-33T) operating in the psychrometeric-mode. The output in microvolts was converted to pascals based on calibration of each psychrometer with $\mathrm{NaCl}$ solutions of known water potential.

After one day from transplanting, the seedlings were transferred to salinized nutrient solution containing $85 \mathrm{~mol} \mathrm{~m}^{-3} \mathrm{NaCl}(-3.0$ bars) with or without the addition of PEG 6000 ( -2.0 bars, $\left.45 \mathrm{gL}^{-1}\right)$. The containers were then transferred to green house at a constant temperature $29 / 21^{\circ} \mathrm{C}$ (day/night). The $\mathrm{pH}$ of the solutions were adjusted to 6.0 daily. Solutions were renewed weekly. Plants were grown up to 30 days in the salinized solutions and the survival of the plants was followed.

Table 1. Composition of nutrient solution ${ }^{a}$

\begin{tabular}{|c|l|c|}
\hline Element & \multicolumn{1}{|c|}{ Reagent } & $\begin{array}{c}\text { Concentration } \\
\text { of element } \\
\text { (mg/l) }\end{array}$ \\
\hline $\mathrm{N}$ & $\mathrm{NH}_{4} \mathrm{NO}_{3}$ & 40 \\
$\mathrm{P}$ & $\mathrm{NaH}_{2} \mathrm{PO}_{4} \cdot 2 \mathrm{H}_{2} \mathrm{O}$ & 10 \\
$\mathrm{~K}$ & $\mathrm{~K}_{2} \mathrm{SO}_{4}$ & 40 \\
$\mathrm{Ca}$ & $\mathrm{CaCl}_{2}$ & 40 \\
$\mathrm{Mg}$ & $\mathrm{MgSO}_{4} \cdot 7 \mathrm{H}_{2} \mathrm{O}$ & 40 \\
$\mathrm{Mn}$ & $\mathrm{MnCl}_{2} \cdot 4 \mathrm{H}_{2} \mathrm{O}$ & 0.5 \\
$\mathrm{Mo}$ & $\left(\mathrm{NH}_{4}\right)_{6} \cdot \mathrm{MO}_{7} \mathrm{O}_{24 .} 4 \mathrm{H}_{2} \mathrm{O}$ & 0.05 \\
$\mathrm{~B}$ & $\mathrm{H}_{3} \mathrm{BO}_{3}$ & 0.2 \\
$\mathrm{Zn}$ & $\mathrm{ZnSO}_{4} .7 \mathrm{H}_{2} \mathrm{O}$ & 0.01 \\
$\mathrm{Cu}$ & $\mathrm{CuSO}_{4} \cdot 5 \mathrm{H}_{2} \mathrm{O}$ & 0.01 \\
$\mathrm{Fe}$ & $\mathrm{FeCl}_{3} 6 \mathrm{H}_{2} \mathrm{O}$ & 2.0 \\
\hline
\end{tabular}

a Yoshida et al (1976).

Experiment 2: Nonosmotic effect of polyethylene Glycols (PEG) upon growth, sodium and chloride transport

The present experiment attempt to determine the effect of salinity $\left(85 \mathrm{~mol} \mathrm{~m}^{-3} \mathrm{NaCl}\right)$ with or without PEG 6000 on growth, uptake and transport of sodium and chloride in two rice varieties varying in salt tolerance. Experimental procedure for the study was same as described in experiment 1 . The amount of PEG 6000 needed to bring the osmotic potential of the nutrient solution to a desired level was same as described in experiment (1). 
After one day from transplanting, the seedlings were transferred to salinized nutrient solution containing $85 \mathrm{~mol} \mathrm{~m}^{-3} \mathrm{NaCl}$ (-3.0 bars) with or without the addition of a variable PEG 6000 at $(-0.5$ bar, 11 $\mathrm{g} \mathrm{L}^{-1}$ ), with an initial $\mathrm{pH}$ of 6.0 . The containers were then transferred to the green house under natural daylight. The $\mathrm{pH}$ of the solutions were adjusted to 6.0 every day. Plants were harvested after 6 days from salinization. After harvest, plant were first washed with tap water several times and then rinsed in deionized distilled water three times and blotted dry. Each plant was divided into shoot and root. Fractions were dried in an oven at $80^{\circ} \mathrm{C}$, then subjected to determination of $\mathrm{Na}$ and $\mathrm{Cl}$ contents, which were extracted in distilled water and analyzed, data were recorded on following aspects: (1) dry weight of root and shoot, (2) sodium and $\mathrm{Cl}$ content of root and shoot that were determined using procedures described in A.O.A.C. (1990).

The data were statistically analyzed according to the technique of analysis of variance (ANOVA) of randomized complete block design by Snedecor and Cochran (1990).

\section{RESULTS AND DISCUSSION}

\section{Survival of seedlings in salinity}

The survival percentage of IR28 and Nona Bokra seedlings are shown in Fig. (1).
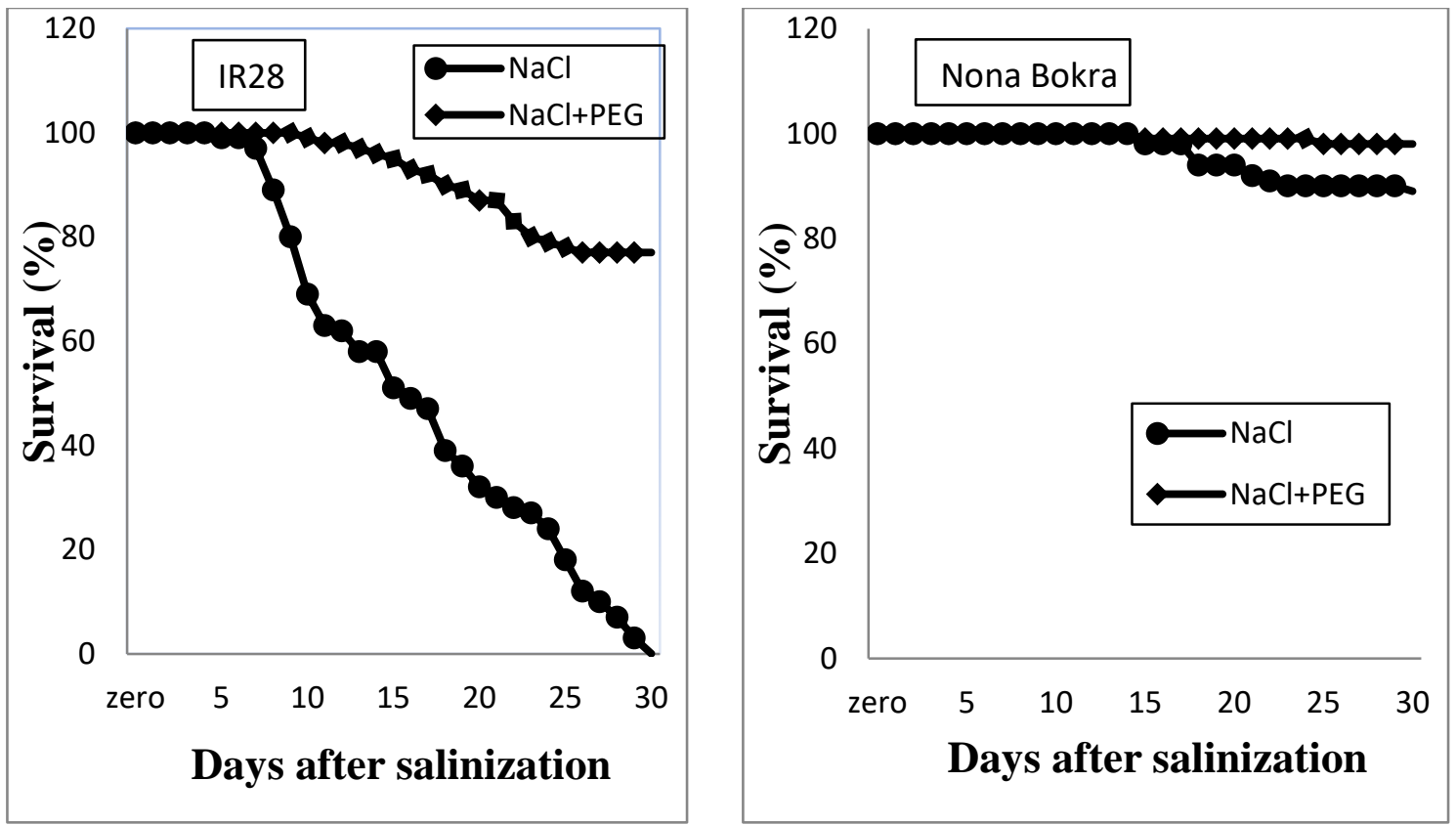

Fig. 1. Time course of survival (\% alive) of IR28 and Nona Bokra seedlings salinized with $\mathrm{NaCl}(85 \mathrm{~mol}$ $\mathrm{m}^{-3}$ ) with or without PEG.

Survival was increased significantly by adding PEG (-2.0 bars) although PEG addition clearly lowers the water potential of the medium, approximately double that of $\mathrm{NaCl}$ alone. After 30 days with salt alone, $100 \%$ of IR28 plants were recorded dead. The salt tolerant variety (Nona Bokra) survived for more than 30 days at exposure to $\mathrm{NaCl}$ with and without PEG. Survival of Nona Bokra was increased significantly by adding PEG (-2.0 bars) to the saline medium $\left(85 \mathrm{~mol} \mathrm{~m}^{-3} \mathrm{NaCl}\right)$. Addition of PEG greatly reduced the rate of death of seedlings compared with $\mathrm{NaCl}$ alone. After 30 days with
$\mathrm{NaCl}$ alone, $11 \%$ of Nona Bokra seedlings were reported dead. PEG greatly reduced this value to $2 \%$. The effect of the time of salinization on survival of IR28 and Nona Bokra was highly significant. Claes et al (1990) mentioned that PEG is a nonionic (neutral polymer), it has high solubility in water and low toxicity to mammals. Because it cannot penetrate the cell membrane, the composition of the cell is not affected. Polyethylene-glycol causes the mimic specific levels of water stress due to drought (Attree and Fowke, 1993). 
The results of this study indicated that, at 85 $\mathrm{mol} \mathrm{m}^{-3}$ of $\mathrm{NaCl}$, salinity damage was unlikely to be due to water stress since the combined treatment $(\mathrm{NaCl}+\mathrm{PEG})$ had the lower water potential but permitted the better survival and seems primarily as $\mathrm{Na}$ and $\mathrm{Cl}$ ion toxicity. This is a further suggestion that growth reduction of rice in saline conditions was not attributable to water stress per se. This finding is similar to that reported by Silveria et al (2009).

\section{Effects of PEG on growth, $\mathrm{Na}$ and $\mathrm{Cl}$ concentra- tion}

An observation of considerable importance in relation to the mechanism of salt injury was that the $\mathrm{NaCl}+$ PEG plants survived so well. They were subjected to approximately twice the osmotic stress experienced by the plants treated with $\mathrm{NaCl}$ alone, yet they showed far less injury. It seems, then, most unlikely that salt injury at this concentration $\left(85 \mathrm{~mol} \mathrm{~m}^{-3}\right)$ was mediated by osmotic factors and much more probable that it was mediated by specific ion toxicity.

Table (2) summarize the data for root and shoot growth, as measured by dry weight, after 6 days of salinity stress with or without PEG. The results show that root and shoot dry weight of the two tested varieties increased significantly with the addition of $11 \mathrm{~g} \mathrm{PEG} \mathrm{L}^{-1}$ to the saline medium. However, increasing the rate of dry weight of root and shoot after the addition of 22 and $44 \mathrm{gL}^{-1}$ was very small and insignificant. Measurement of plant growth are important to separate the effects of the osmotic and ionic stress components, which domi- nate plant growth at different times (Munns and Tester, 2008).

The data of $\mathrm{Na}$ and $\mathrm{Cl}$ concentration by IR28 and Nona Bokra varieties as affected by adding PEG to the saline medium are presented in Tables (3 and 4). During the 6 days experimental period, PEG 6000 (11 $\mathrm{gL}^{-1},-0.5$ bar) reduced sodium concentration in root of IR28 and Nona Bokra but its effect on sodium concentration in shoot of the two varieties was more pronounced than the reduction in root sodium concentration. Polyethylene-glycol 6000 (-0.5 bar) reduced shoot sodium concentration from $3.36 \%$ to $0.90 \%$ in IR28 and from $2.36 \%$ to $0.63 \%$ in Nona Bokra. The results showed significant differences between zero and the other concentrations of PEG.

The results of this study are strongly indicated that addition of PEG dramatically lessened the toxicity of $\mathrm{NaCl}$ to rice seedlings. This was explained by a reduction in the uptake of $\mathrm{Na}^{+}$and $\mathrm{Cl}^{-}$ and the greater effect upon shoot $\mathrm{Na}^{+}$concentration than root $\mathrm{Na}^{+}$concentration. This result is in agreement with that of Quintero et al (2008) who reported that many mechanisms of plant tolerance under high soil salinity were related to the maintenance of low $\mathrm{Na}^{+}$in shoots. Exclusion of $\mathrm{Na}^{+}$ion and its distribution in all leaves were related to salt tolerance (Haq et al 2009). Metabolism of diving and expanding cells was inhibited by high intracellular concentrations of both $\mathrm{Na}^{+}$and $\mathrm{Cl}^{-}$(Neumann, 1997). Osmotic effects solely cause the inhibition of germination in PEG-treated seeds and generally, ionic effects cause the difference in germination of salt-treated relative to PEG-treated seeds (Dodd and Donovan, 1999).

Table 2. Shoot and root dry weight of IR28 and Nona Bokra grown for 6 days in $\mathrm{NaCl}(85 \mathrm{~mol}$ $\mathrm{m}^{-3}$ ) with and without different concentrations of PEG 6000

\begin{tabular}{|c|c|c|c|c|c|c|}
\hline \multirow{3}{*}{ PEG treatments $\left(\mathrm{gL}^{-1}\right)$} & \multicolumn{6}{|c|}{ Dry weight (g/tray) } \\
\hline & \multicolumn{3}{|c|}{ Root } & \multicolumn{3}{|c|}{ Shoot } \\
\hline & IR28 & $\begin{array}{l}\text { Nona } \\
\text { Bokra }\end{array}$ & $\begin{array}{l}\text { PEG- } \\
\text { means }\end{array}$ & IR28 & $\begin{array}{l}\text { Nona } \\
\text { Bokra }\end{array}$ & $\begin{array}{l}\text { PEG- } \\
\text { means }\end{array}$ \\
\hline 0 & 0.138 & 0.340 & 0.239 & 0.596 & 1.358 & 0.977 \\
\hline 11 & 0.239 & 0.513 & 0.376 & 0.831 & 1.647 & 1.239 \\
\hline 22 & 0.282 & 0.504 & 0.393 & 0.823 & 1.666 & 1.245 \\
\hline 44 & 0.316 & 0.518 & 0.417 & 0.857 & 1.653 & 1.255 \\
\hline Variety - means & 0.244 & 0.469 & -- & 0.777 & 1.581 & -- \\
\hline $\begin{array}{l}\text { LSD }_{0.05} \text { for } \\
\text { PEG } \\
\text { Variety }\end{array}$ & & $\begin{array}{l}0.110 \\
0.119\end{array}$ & & & $\begin{array}{l}0.070 \\
0.046\end{array}$ & \\
\hline
\end{tabular}


Table 3. Sodium ion content (\%) in root and shoot of IR28 and Nona Bokra grown for 6 days in $\mathrm{NaCl}\left(85 \mathrm{~mol} \mathrm{~m}^{-3}\right)$ with and without different concentrations of PEG 6000

\begin{tabular}{|c|c|c|c|c|c|c|}
\hline \multirow{3}{*}{ PEG treatments $\left(\mathrm{gL}^{-1}\right)$} & \multicolumn{6}{|c|}{ Sodium ion content (\%) } \\
\hline & \multicolumn{3}{|c|}{ Root } & \multicolumn{3}{|c|}{ Shoot } \\
\hline & IR28 & $\begin{array}{l}\text { Nona } \\
\text { Bokra }\end{array}$ & $\begin{array}{l}\text { PEG- } \\
\text { means }\end{array}$ & IR28 & $\begin{array}{c}\text { Nona } \\
\text { Bokra. }\end{array}$ & $\begin{array}{l}\text { PEG- } \\
\text { means }\end{array}$ \\
\hline 0 & 1.60 & 2.43 & 2.02 & 3.36 & 2.36 & \\
\hline 11 & 1.28 & 1.45 & 1.37 & 0.90 & 0.63 & 0.77 \\
\hline 22 & 1.29 & 1.35 & 1.32 & 0.92 & 0.84 & 0.87 \\
\hline 44 & 1.13 & 1.23 & 1.18 & 0.71 & 0.62 & 0.67 \\
\hline Variety - means & 1.33 & 1.62 & - & 1.47 & 1.11 & - \\
\hline $\begin{array}{l}\text { LSD }_{0.05} \text { for } \\
\text { PEG } \\
\text { Variety }\end{array}$ & & $\begin{array}{l}0.044 \\
0.029\end{array}$ & & & $\begin{array}{l}0.027 \\
0.172\end{array}$ & \\
\hline
\end{tabular}

Table 4. Chloride ion content (\%) in root and shoot of IR28 and Nona Bokra grown for 6 days in $\mathrm{NaCl}\left(85 \mathrm{~mol} \mathrm{~m}^{-3}\right)$ with and without different concentrations of PEG 6000

\begin{tabular}{|c|c|c|c|c|c|c|}
\hline \multirow{3}{*}{ PEG treatments $\left(\mathrm{gL}^{-1}\right)$} & \multicolumn{6}{|c|}{ Chloride ion content (\%) } \\
\hline & \multicolumn{3}{|c|}{ Root } & \multicolumn{3}{|c|}{ Shoot } \\
\hline & IR28 & $\begin{array}{l}\text { Nona } \\
\text { Bokra }\end{array}$ & $\begin{array}{l}\text { PEG- } \\
\text { means }\end{array}$ & IR28 & $\begin{array}{l}\text { Nona } \\
\text { Bokra }\end{array}$ & $\begin{array}{l}\text { PEG- } \\
\text { means }\end{array}$ \\
\hline 0 & 1.90 & 2.87 & & 5.94 & 4.04 & \\
\hline 11 & 1.83 & 2.46 & 2.15 & 2.59 & 2.46 & 2.53 \\
\hline 22 & 1.66 & 2.29 & 1.98 & 2.69 & 2.36 & 2.53 \\
\hline 44 & 1.52 & 1.99 & 1.76 & 1.99 & 1.99 & 1.99 \\
\hline Variety - means & 1.73 & 2.40 & -- & 3.30 & 2.71 & -- \\
\hline $\begin{array}{l}\text { LSD }_{0.05} \text { for } \\
\text { PEG } \\
\text { Variety }\end{array}$ & & $\begin{array}{l}0.017 \\
0.011\end{array}$ & & & $\begin{array}{l}0.012 \\
0.023\end{array}$ & \\
\hline
\end{tabular}

\section{REFERENCES}

A.O.A.C. 1990. Official Methods of Analysis Association of official analytical chemists, $15^{\text {th }} \mathrm{Ed}$. Inc Washington D.C.

Attree, S.M. and Fowke, L.C. 1993. Somatic embrrogenesis and synthetic seeds of conifers. Plant Cell Tissue Org. Cult. 35, 1-35.

Claes, B., Dekeyser, R., Villaroet, R., VandenBulcke, M., Bauw, G., Montagn, M. and Caplan, A. 1990. Characterization of a rice gene showing organ - specific expression in response to salt stress and drought. Plant Cell, 2, 19-27.
Darwish, E., Testerink, C., Khalil, M., El-Shihy, O. and Munnik, T. 2009. Phospholipid signaling responses in salt-stressed rice leaves. Plant Cell Physiol. 50(5), 986-997.

Dodd, G.L. and Donovan, L.A.1999. Water potential and ionic effects on germination and seedling growth of two cold desert shrubs. American Journal of Botany, 86, 1146-1153.

Hag, T., Akhtar, J., Nawaz, S. and Ahmed, R. 2009. Morpho-physiological response of rice (Oryza sativa L.) varieties to salinity stress. Pak. J. Bot. 41(6), 1943-2956.

Hasegawa, P.M., Bressnan, R.A., Zhu, J.K. and Bohnert, H.J. 2000. Plant cellular and molecu- 
lar responses to high salinity. Annual Review of Plant Physiology and Plant Molecular Biology Review of Plant Physiology and Plant Molecular Biology 51, 463-499.

Lawlor, D.W. 1970. Absorption of polyethylene glycols by plants and their effects on plant growth New Phytol, 69, 501-513.

Maathuis, F.J.M. and Amtmann, A. 1999. $\mathrm{K}^{+}$nutrition and $\mathrm{Na}^{+}$toxicity: the basis of cellular $\mathrm{K} / \mathrm{Na}$ ratios. Ann. Bot. 42, 123-133.

Moisender, P.H., McClinton, E. and Paerl, H.W. 2002. Salinity effects on growth, photosynthetic parameters, and nitrogenase activity in estuarine planktonic cyanobacteria. Microbiology and Ecology 43, 432-442.

Munns, R. and Tester, M. 2008. Mechanisms of salinity tolerance. Annu. Rev. Plant Biol. 59, 651-681.

Murphy, K.S.T. and Durako, M.J. 2003. Physiological effects of short term salinity changes on Ruppiamaritima. Aquatic Botany 75, 293-309.

Neumann, P. 1997. Salinity resistance and plant growth revisited. Plant Cell and Environment, 20, 1193-1198.

Pagter, M., Bragato, C., Malagori, M. and Brix, H. 2009. Osmotic and ionic effects of $\mathrm{NaCl}$ and $\mathrm{Na}_{2} \mathrm{SO}_{4}$ salinity on Phragmites australis. Aquat. Bot. 90, 43-51.
Quintero, JM., Fournier, JM., Benlloch, M. and Rodriguez - Navarro, A. 2008. $\mathrm{Na}^{+}$accumulation in root symplast of sunflower plants exposed to moderate salinity is transpiration dependent. J. Plant Physiol. 165,1248-1254.

Shabala, S. and Munns, R. 2012. Salinity stress: Physiological constraints and adaptive mechanisms. In: Shabala, S. (ed.). Plant Stress Physiology. CAB. International, Wallingford, UK. pp. 59-93.

Silveria, J.A.G., Araujo, S.A.M., Lima, J.P.M.S. and Viegas, R.A. 2009. Roots and leaves display contrasting osmotic adjustment mechanisms in response to $\mathrm{NaCl}$ salinity in Atriplex nummularia. Experimental and Enivronmental Botany, 66, 1-8.

Siringam, K., Juntawong, N., Cha-um, S. and Kirdmanee, C. 2011. Salt stress induced ion accumulation, ion homeostasis, membrane injury and sugar contents in salt sensitive rice (Oryza Sativa L. spp. Indica) roots under isoosmotic conditions. Afr. J. Biotech. 10(8), 1340-1346.

Snedecor, G.W. and Cochran, W.G. 1990. Statistical Methods $\left(7^{\text {th }}\right.$ ed.). Ames, IA: lowa State University Press. 507 p.

Yoshida, S., Forno, D.A., Cock, J.H. and Gomez, K.A. 1976. Laboratory manual for-physiological studies of rice, IRRI, Los Bano, Philippines. $\mathbf{8 3}$ p. 